\title{
DEVELOPING SYLLABUS OF ARABIC LANGUAGE'S PRODUCTIVE COMPETENCE BASED ON CONTENT LANGUAGE INTEGRATED LEARNING (CLIL)
}

\author{
Yumna Rasyid ${ }^{1}$, Puti Zulharby ${ }^{2}$. \\ State University of Jakarta \\ yumna.rasyid@unj.ac.id ${ }^{1}$ \\ puti.zulharby@unj.ac.id ${ }^{2}$
}

\begin{abstract}
Abstrack
The objective of this research is to acquire deep understanding of the developing syllabus of Arabic language's productive competence based on content language integrated learning at Arabic language teaching department. Focus of this research is: the model of syllabus of Arabic language productive competence. This research was conducted from July 2015 until February 2016 .The research method used in this study is a research development with a qualitative approach to content. The approach used in analyzing the analysis of students need. The research instrument is the researcher herself who is equipped with table analysis. The result showed that Based on an analysis of documents of syllabus productive skills that are currently used in the Department of Arabic Language and Literature, State University of Jakarta focusing on the themes that have been determined for each meeting. How syllabus like this had not yet shown the achievements of the expected learning, so that the study sought to develop a syllabus based on the needs of learners with the approach of the syllabus-based CLIL (Content Language Integrated Learning).
\end{abstract}

Keywords: Syllabus Development, Productive Competence, Arabic Language

The development of language syllabus is one of main aspects to be considered in the implementation of language program. The development of syllabus is related with the effort to supply/procure guidelines for teachers to carry out the language teaching and learning, both in the classroom and outside the classroom in achieving the predetermined goals. The development of language syllabus is not instant activities in short time, but the development of syllabus requires a quite long process which includes several stages, such as analysis of syllabus that is being used, student need analysis, and testing of produced syllabus and implementation of the syllabus in teaching because an effective learning is one that is suitable to the needs of learners. The need analysis is very necessary to know what the learners actually need at the end of the course so that the institutions can adjust the syllabus to the learners' needs. The needs analysis is expected to create continuity between the students' needs and the institution's purposes. 
This study focuses on the Arabic Language's basic productive skills syllabus namely Basic Speaking (al-kalam I) and Basic Writing (al-kitabah I) in the Department of Arabic Language and Literature, State University of Jakarta. The productive skills syllabus that is currently used in the Department of Arabic Language and Literature, State University of Jakarta, focuses on the themes that have been determined for each meeting. Of any themes that have been determined, the competences to be achieved are still generalized. In the basic writing skill (Kitabah I), for example, the expected competency is that the students are capable of structuring words and phrases in simple sentences and capable of writing guided paragraphs and capable of making and writing sentences on predetermined topics and capable of doing the exercises associated with prescribed titles. Likewise, in the basic speaking skill (Kalam I), the expected competencies of each meeting are also generalized, that is, the students is capable of mimicking the patterns of sentences in the text, capable of conducting guided conversations, capable of expressing the events according to the picture presented and capable of changing the structure and retelling the content of a text.

Such method of development of syllabus has not shown the achievements of the expected learning, so that this study is seeking to develop a syllabus based on the needs of learners with the CLIL (Content Language Integrated Learning)based syllabus approach, which in Indonesian is commonly called as Pembelajaran Terpadu Isi dan Bahasa [Content and Language Integrated Learning]. CLIL is an approach to learning that teach the content of courses through communication media and learning media which do not come from the first language, but with communication media by using the target language that is Arabic. This CLIL approach is trying to create a natural language learning condition with emphasis on learning the meaning and selecting the basic themes that are drastically increase the number of vocabulary of learners in Speaking I (al-kalam I) and Writing I (alkitabah I) .

The CLIL approach integrates the contents of topics studied in the used target language, so that in the implementation, the second language acquisition will be successfully achieved if the learning condition is the same as one of the first language acquisition so that students become proficient in speaking the language.

The CLIL concept if it is connected with course of Speaking I (al-kalam I) and Writing I (al-kitabah I) is very appropriate because this approach focuses on learning the meaning which can increase the students' vocabularies. As example in the course of Speaking I (al-kalam I), the achievements of this learning is that the students are expected to be able to do dialogue about the themes and situations which have been determined by the teacher. The determined themes can be selected based on the dialogue that routinely occurs in everyday life. Thus, at the meeting the target of learning activities will be achieved more easily because learning situation is adapted to the conditions of first language acquisition, while the number of vocabularies acquired by the students can be increased drastically. 


\section{METHOD}

This research is based on the qualitative paradigm with Research and Development Method. The qualitative approach is research that describes and illustrates a systematic, factual and accurate manner about the facts, characteristics and phenomena relationship studied qualitatively.

This development research is developed based on research findings in the field of education that is used to design new products and procedures, and then is systematically tested in the field, evaluated, and revised so as to find the criteria of the effectiveness, quality, or standard. Moleong (2005: 157) pointed out that the sources of primary data in the qualitative research are words and actions, while the remaining are additional data such as documents, photos, artifacts and statistics.

This research was conducted with the following steps (1) problem identification; (2) information collection, to assess the needs of the user community; (3) product design, after analyzing the needs, the design of products is developed; (4) design validity, product design assessment process conducted with rating based on the premise without field trials which are usually done by experts; (5) design revisions, the revisions are made based on expert judgment; (6) product trials, conducted to determine the effectiveness of the developed products; (7) product revision, conducted because the test is still limited, there are still weaknesses and shortcomings, the revised data can be captured through the product; (8) utility testing, conducted on a wider group; (9) final production revision, (10) mass production (Moleong, 2013: 298-304).

The development of research steps is illustrated by Sugiyono as follows.

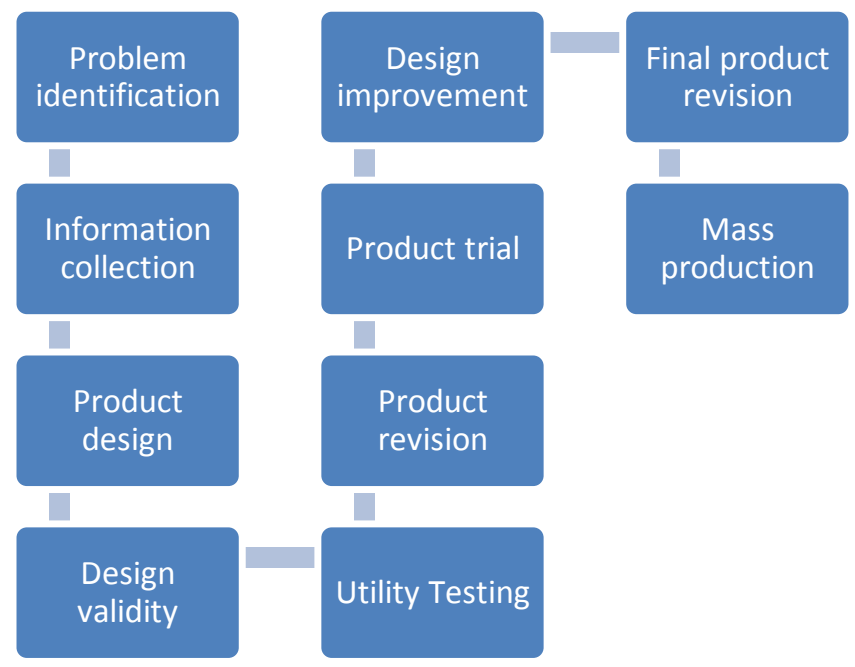

Figure 1.1 Steps of Research and Development 


\section{RESULTS}

The results of development research of basic skills syllabus employed three sources of information: 1) document of syllabus, 2) analysis of needs, and 3) analysis of situation. The entire resources of information were obtained in the Arabic Language Study Program, Faculty of Language and Art, State University of Jakarta.

Based on the analysis of documents of productive skills syllabus of basic writing (Kitabah I), it was found that the purpose of the study was that students had the capability of structuring the words and phrases in simple sentences and capability of guided writing.

Based on the analysis of needs about the language skills to be developed periodically, speaking capability (Kalam) occupied the top position, followed by the writing capability (Kitabah). This shows that the productive skills are skills that students want to master and will be developed regularly given that the two (2) productive skills are regarded as very important skills in learning Arabic because speaking and writing are applicable the language and early goal of anyone who are learning the language.

\section{Skill to Be Developed Periodically}

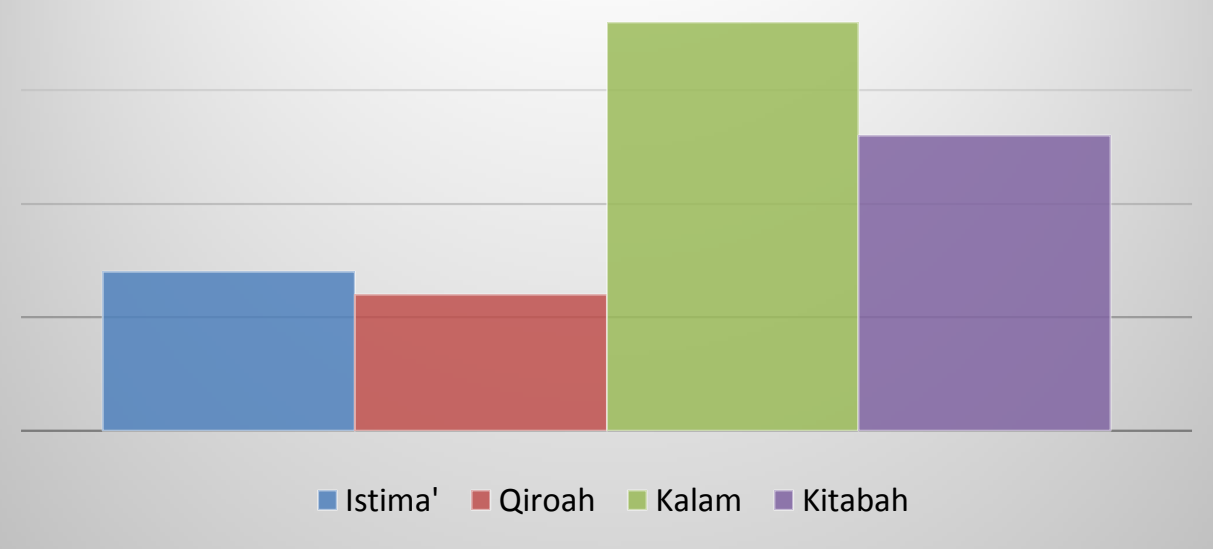

Figure 2.1 Skills To Be Developed Periodically 


\section{Difficulties Frequently Found}

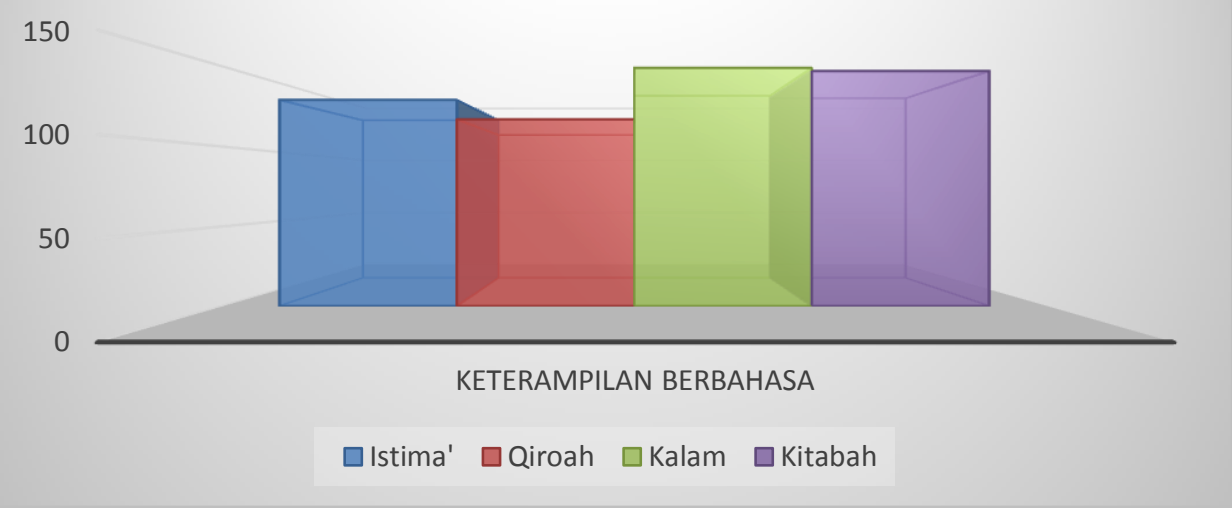

Figure 4.2 Difficulties Frequently Found

With respect to relation between the effects of mastery of language skills and the value of course as a whole, it was also found that the speaking skills have a huge impact on supporting the overall value of course in the Department of Arabic Language and Literature. It was followed by writing skill (Kitabah) and reading (Qiroah) in supporting the value of course.

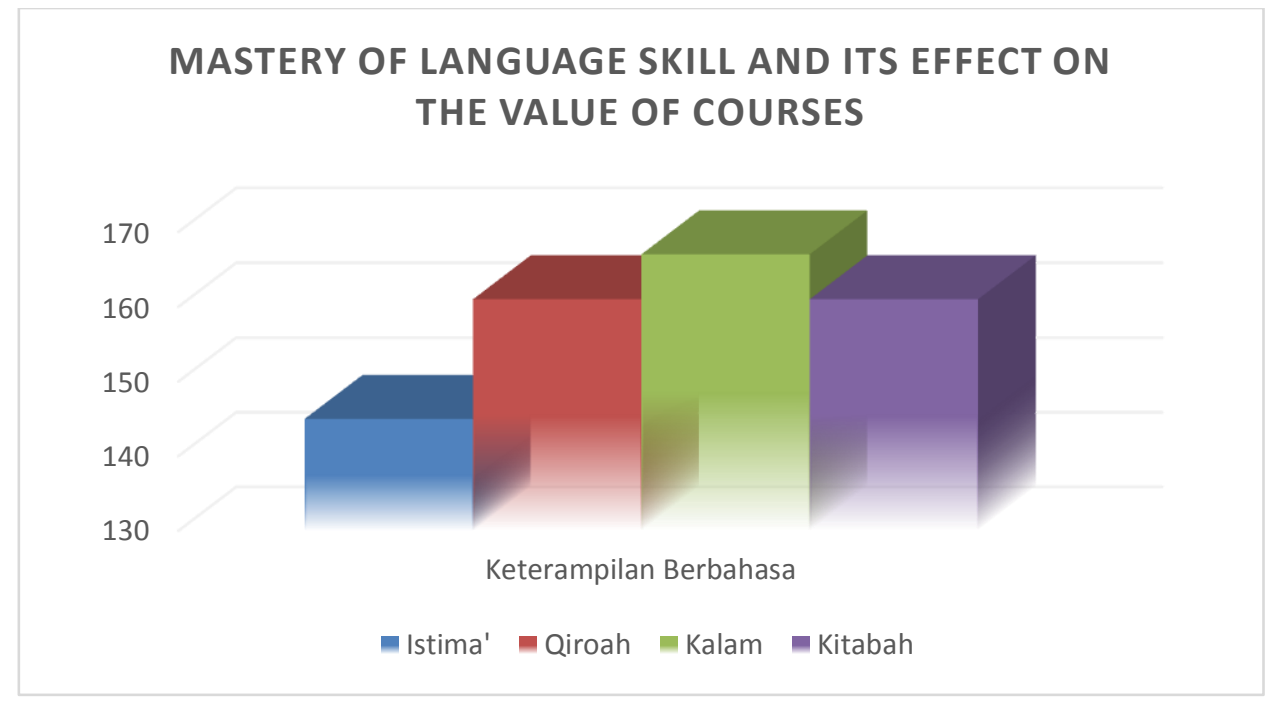

Figure 4.3 Mastery of language skill and its effect on the value of courses

Meanwhile regarding the link between the effect of mastery of language skill and communications applications outside the course or in the field, speaking skill (Kalam) is highly influential given that the ability to speak Arabic is process of individuals to communicate with the communities who speak Arabic to declare him/her as a member of the communities. 


\section{MASTERY OF LANGUAGE SKILL AND ITS INFLUENCE ON COMMUNICATION OUTSIDE COURSE}

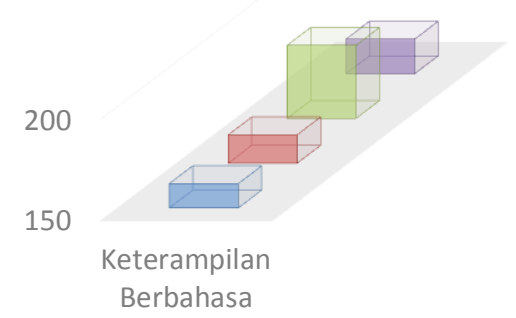

Figure 4.4 Mastery of Language Skill and its Influence on Communication Applications Outside of Course

Based on the above analysis, it was found that the productive skill of speaking and writing have big impact and influence for Arabic language student both in the course and in communication applications in the field, and the author also designed the analysis of special needs to find out the difficulties faced by students in comprehending these 2 (two) skills.

Based on 10 (ten) indicators, it was found that the 5 (five) highest difficulties that often occurred in students who were studying basic speaking skills (Kalam I) were 1) difficulty in quick speaking with Arabic (Indicator 10), 2) afraid wrong in talking (Indicator 9), 3) problems in the argument in the classroom by using Arabic (Indicator 5), 4) difficulties in using a good Arabic grammar (Indicator 7), and 5) difficulties in chairing the class discussion using Arabic language (Indicator 4).

\section{DIFFICULTIES FACED IN DEEPENING THE BASIC SPEAKING PRODUCTIVE SKILL (KALAM I)}

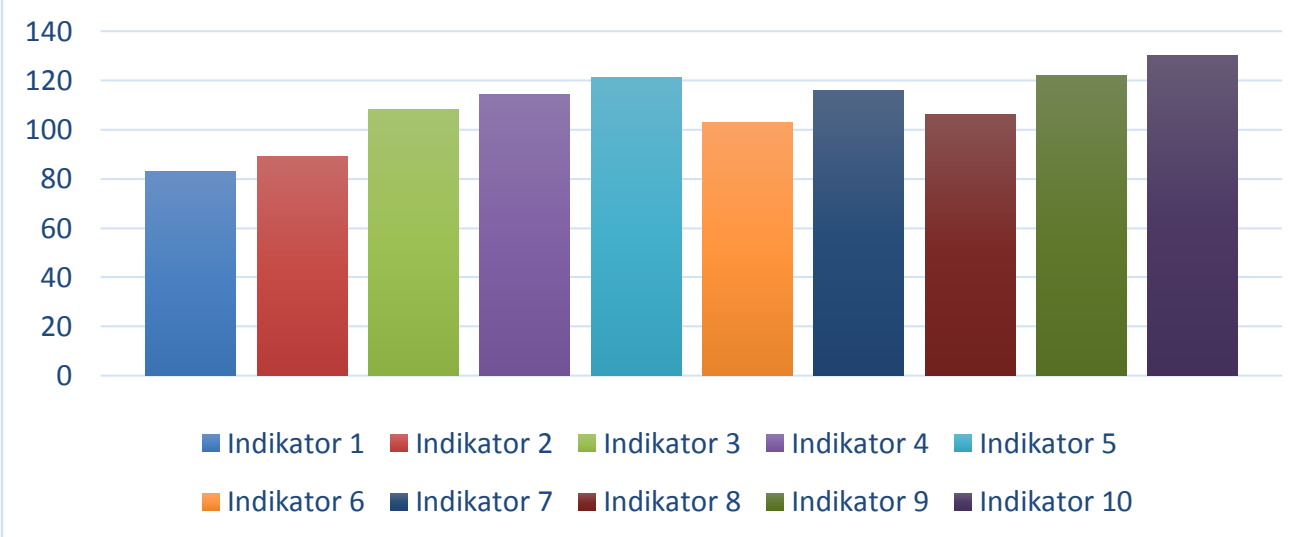

Figure 4.5 Difficulties faced in deepening the basic speaking productive skills (Kalam I) 
Second, in deepening the basic writing skills, the authors designed a questionnaire which contained 10 (ten) indicators of difficulties faced when exploring/learning the basic writing skills (Kitabah I), and the students were asked to fill out how important the basic writing competence (Kitabah I) should be explored and how often difficulties occurred when studying this competence. The 10 (ten) indicators were:

$\begin{array}{ll}\text { Indicator 1 } & : \text { Use of punctuation and spelling in writing. } \\ \text { Indicator 2 } & : \text { Structuring words in sentences. } \\ \text { Indicator 3 } & : \text { Use of appropriate vocabularies. } \\ \text { Indicator 4 } & : \text { Composition of the paragraph } \\ \text { Indicator 5 } & : \text { Expressing correct idea in writing. } \\ \text { Indicator 6 } & : \text { Developing an idea. } \\ \text { Indicator 7 } & : \text { Clearly expressing what to be delivered. } \\ \text { Indicator 8 } & : \text { Use of correct grammar. } \\ \text { Indicator 9 } & : \text { Evaluation and revision of what have been written } \\ \text { Indicator 10 } & : \text { Having the writing intelligence }\end{array}$

Based on the 10 (ten) indicators, there were 5 most important components found in deepening the basic writing productive skills (Kitabah I): 1) Use of appropriate vocabularies (Indicator 3), 2) use of punctuation and spelling in writing (Indicator 1), 3) Structuring words in sentences (Indicator 3), 4) Clearly expressing what to be delivered (Indicator 7), and 5) Having the writing intelligence (Indicator 10).

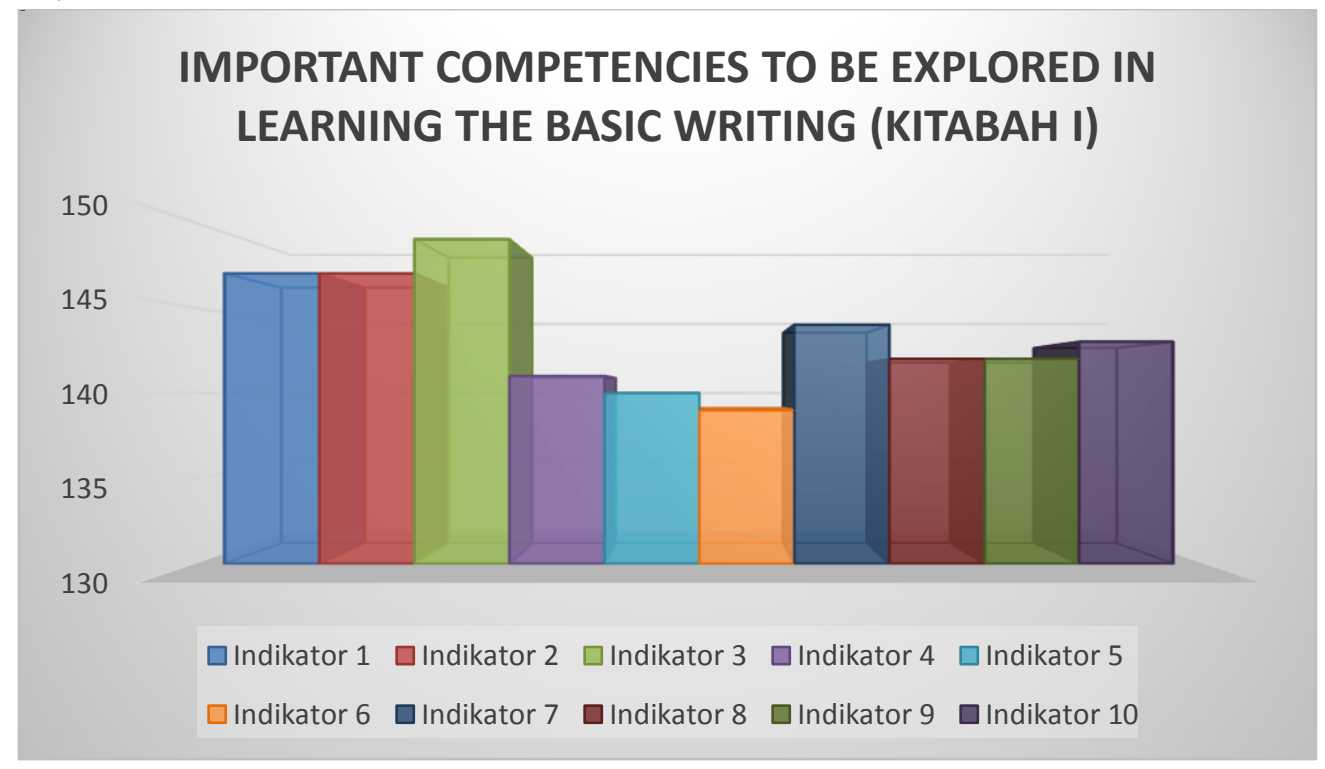

Figure 4.6 Important competencies to be deepened in the Basic Writing Learning (Kitabah I) 
Based on the ten (10) most important components in deepening the basic writing skill (Kitabah I), there were 5 difficulties that frequently arise when the students were deepening it: 1) use of correct grammar (Indicator 8), 2) Expressing correct idea in writing (Indicator 5), 3) Developing an idea (Indicator 6), 4) Clearly expressing what to be delivered (Indicator 7), 5) having the writing intelligence (Indicator 10).

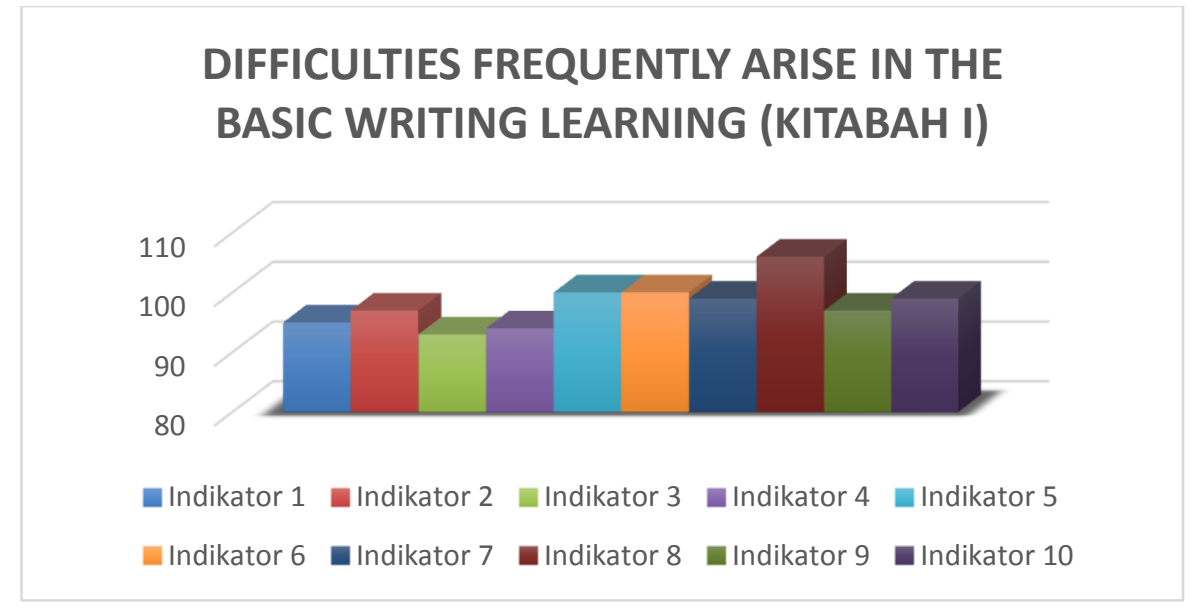

Figure 4.7 Difficulties frequently arise in the basic writing learning

In the Department of Arabic Language and Literature, State University of Jakarta, the educational background of Arabic language student was fairly suitable with the Department's qualifications. This is reflected from the fact that the students coming from schools that previously had studied the Arabic language were more able to understand the lesson. Unlike them, the students coming from schools that previously had not studied Arabic language usually lacked of understanding the lesson in the early stages of course so that they needed more learning to study the advance material as they did not have Arabic learning background.

Some problems about learning difficulties of Arabic productive skills found in the Department of Arabic Language and Literature, State University of Jakarta were the lack of speaking and writing productivity and the lack of reading comprehension of texts that therefore contributed to their lack vocabularies, as well as the less conducive language environment that also makes difficult to develop the speaking productive ability.

Based on document analysis, need analysis, and situation analysis, then here is a design model of development of productive skills syllabus: 


\section{Syllabus of Basic Writing Skills (Kitabah I) Based on CLIL}

In practice to increase the basic writing skills, there are some strategies prepared in exercise of kitabah (writing), including: 1) imitating and copying, 2) Reproduction 3) recombination and transformation, 4) guided composing, 5) fee composing. The syllabus designed for basic writing skills based on CLIL contains columns as follows:

1. Topic and Time Allocation

2. Learning Achievement

a. In terms of knowledge: achieved competencies in terms of knowledge of vocabularies, term of word, context of word usage, grammar and structure that must be mastered by the students in the topic/theme studied.

b. In terms of skill: form of knowledge, ability to be achieved by students by applying, implementing and expressing the idea of Arabic grammar into written language based on the topic studied.

3. Contents of material

a. Subject matter: outline of contents of subject provided in order to achieve the purpose/objective.

b. Sub subject matter: components/details of each item that reflects the details of the subject, which is consistent with the Subject matter.

4. Learning activities

a. Lecturer: Lecturer activities during lecture hours take place

b. Students: Student activities conducted during lecture hours take place.

c. Methods: Overall Planning prepared for learning.

d. Learning techniques: Techniques used by lecturers in learning.

e. Learning Media: Media used by lecturers in learning.

5. Evaluation

\section{Syllabus of Basic Speaking Skills (Kalam I) Based on CLIL}

Syllabus designed for basic writing skills based on CLIL contains columns as follows:

1. Topic and Time Allocation

2. Learning Achievement

a. In terms of knowledge: achieved competencies in terms of knowledge of vocabularies, term of word, context of word usage, grammar and structure that must be mastered by the students in the topic/theme studied.

b. In terms of skill: form of knowledge, ability to be achieved by students by applying, implementing and expressing the idea of Arabic grammar into written language based on the topic studied.

3. Contents of material

a. Subject matter: outline of contents of subject provided in order to achieve the purpose/objective. 
b. Sub subject matter: components/details of each item that reflects the details of the subject, which is consistent with the Subject matter.

4. Learning activities

a. Lecturer: Lecturer activities during lecture hours take place

b. Students: Student activities conducted during lecture hours take place.

c. Methods: Overall Planning prepared for learning.

d. Learning techniques: Techniques used by lecturers in learning.

e. Learning Media: Media used by lecturers in learning.

5. Evaluation

\section{DISCUSSION}

According to Richards (2005:3), curriculum is a more comprehensive assessment than the syllabus, because the curriculum covers the entire process of learning including needs of participants (teachers, pupils, schools) in learning. In the curriculum, learning programs should be developed toward purpose, learning structure, teaching methods, learning materials, and evaluation, as has been quoted from his book:

Curriculum development is a more comprehensive processes than syllabus design. it includes the processes that are used to determinate the needs of a group learners, to develop aims or objectives for a program to adress those needs, to determine an appropriate syllabus, course structure, teaching methode, and materials, and to carry out an evaluation of the language program that results from these processes

Detail definition about curriculum concept is expressed by Glatlhorn (2008: 131). He points out that curriculum is created to guide the planning of learning in schools. The curriculum is presented in the form of documents which may be revised from several levels or classes and in the form of general statements. The implementation of curriculum planning is then carried out in the classroom.

In contrast to the concept of curriculum proposed by Mc Kernan (2008:4), the curriculum is an educational policy plan offered by the school or educational institution. Curriculum content consists of valuable knowledge, values, skills, and other dispositions planned intensively. The curriculum serves to support education or training.

According to Richards (2005:152), syllabuses describe the main elements that will be used in the language program, and provide the basis for the focus and content of teaching. There are several factors that influence the planning in choosing the syllabus design, namely: (1) Knowledge and Beliefs About the Subject, a syllabus reflects the ideas and beliefs about the nature of listening, reading, speaking and writing; (2) Research and Theory, research on use and learning of language and applied language theory affect the determination of syllabus; (3) Practical Experience, language teaching profession has built up 
practical experience in the development of language programs and provide a basis for selection of type of syllabus; (4) Trends, syllabus design approach turns and reflect the national and international trends.

Syllabus provides the issues that will be learned that include content and learning activities. Mc Kay and Brown (1995: 7) reveal four types of syllabus in language teaching, namely: (1) Structural Syllabus, (2) Situational Syllabus, (3) Topical Syllabus, and (4) Notional Syllabus.

\section{Language syllabus}

In preparing a language syllabus, there are several criteria that must be considered by syllabus compilers. According to Harmer (2001:295), there are several criteria that must be considered as a basis for preparing the syllabus, namely: (1) Learnability, related to structure difficulty level and certain lexical items to be learned by students, (2) frequency, related to the language item most frequently or infrequently used in language activities, (3) Coverage, associated with a few words or structures that include other words or structures, (4) Usefulness, related to proximity of lexical items with daily life of students that will be useful if covered in the class.

In addition, according to Richard (2005: 150) there are several criteria that must be considered in the development and distribution of syllabus content. Those criteria are: (a) simple to complex, the content presented at the beginning should be simpler than content that is granted at the end, in particular the content of language (grammar); (b) chronology, the content can be divided in accordance with the order that occur in the real world, writing learning can be organized in the order as follows: brainstorming, drafting, revising, and editing; (c) need, the content developed should be tailored to the needs of learners outside the classroom; (d) prerequisite learning, the distribution of content /syllabus can reflect that particular part is the basic content of next learning step; (e) whole to part or part to whole, the material at the beginning may focus on overall structure or organization of a topic before presenting the components; (f) spiral sequencing, a restatement of certain items to provide opportunities for learners to repeat.

\section{Needs analysis}

Brown (1995:35) called the term need analysis as needs assessment and both terms are used interchangeably. In the Indonesian language the two terms are translated as analisis kebutuhan. In general, the needs analysis refers to the activity that occurs in gathering information that will provide the basis for development of curriculum or syllabus.

In English requirement/need analysis include jobs of identifying the needs or conditions to be fulfilled in a new product or product changes, which take various needs into account that intersect between various stakeholders. The need is a gap between what is expected and what actual condition is, the desire is the future 
or ideal hopes associated with solution to a problem. Meanwhile, need assessment is a tool to identify problems in order to determine the appropriate action.

Productive skills are the skills after receiving language (receptive). The productive language skills include speaking skill and writing skill. The productive process means the process that takes place on the speakers who produce language codes that are meaningful and useful.

Productive English design process can be divided into three phases namely: 1) semantics encoding, is process of formulating ideas, ideas, or concepts. 2) Grammatical encoding, is preparation of concept or idea in the form of grammatical units. 3) phonology encoding, is preparation of sound of the code which is then thrown to the listener with understanding.

The content and language integrated learning (CLIL) program has many names; in the USA, it is referred to as the content-based instruction (CBI) and bilingual education (BE). In the 1990s the European Commission conducted a research on the use of CLIL in the European continent, from this research emerged approaches, such as the CBI, immersion, BE, and then all of these terms changed into CLIL which was introduced by UNICOM in 1996. The CLIL refers to subjects taught in a foreign language with two objectives: to learn the content, and at the same time learn a foreign language (Zarobe, 2009:24). The CLIL emphasis on content or materials of subject, and the language is a tool to convey the content or material of subject because for learners there is no language learning without follow up of the message to be conveyed. It means the language as a communication tool helps learners to increase their science and knowledge.

The CLIL is an approach to teach the course content through not the first language media. In this case, the Indonesian language is the second language for elementary school students in general. In the CLIL, learners acquire knowledge of understanding the subjects when studying, performing and using the target languages simultaneously. The contents are the words that precede the language because it is the curriculum content that lead the language learning. The learners must develop accuracy in language use. The rationale for development of CLIL, includes:

1. Content: related to the topics to be presented and developed in learning,

2. Communications: related to the language that learners will use during the learning process, ie the language to compare and contrast in order to analyze the similarities and differences between one thing with another.

3. Cognition: associated with thinking skills required to students, for example, to classify, assess, analyze,

4. Culture/Community/citizenship: relates to the culture and values contained around the learners.

The application of the CLIL in language teaching gets a lot of support. Most arguments in favor of the CLIL come from the second language acquisition (SLA) research, and showed that the CLIL would be able to create a natural 
language learning conditions (naturalistic). The CLIL provides a purpose for the use of language in the classroom, has positive influence on language learning by emphasizing on meaning rather than form. The CLIL drastically increase the learners' vocabularies (Zarobe, 2009:25).

Language learning that takes place naturally and more emphasis on the meaning will reduce the psychological pressure on language learners. This will facilitate the learners to master the vocabularies and the language studied. The rationale of integrating contents and language come from Krashen (1982), Ughtbown and Spada (2006), Long (1990), and Swain (2000), who stated that the acquisition of a second language is most successful when in the same condition in the first language acquisition; that is, when the focus of instruction on meaning rather than form, when the input of language is above proficiency of learners, and when there is sufficient opportunity to engage in meaningful use of language in an environment that is relatively free from anxiety. In other words, the learning conditions of most successful second language or foreign language teaching are focused on meaning, language teaching materials given above learners' proficiency, and learners have the opportunity to use the language in their environment.

In addition, Cummins stated that individuals who were learning a language actually developed two types of language proficiency, namely basic interpersonal language and cognitive-academic language proficiency. When interpersonal language skills can be acquired within 1-2 years, the level of proficiency needed to deal with academic context requires 5-7 years to develop. The CLIL offers a way in which learners can continue their cognitive or academic development while they are receive academic language proficiency.

Furthermore, Cummins stated that learning success took place when the task was cognitively demanding being contextualized slowly. The integration of language and subject content offers the possibility to reconcile both conditions. This means that through CLIL learners are easier to learn the language and at the same time acquire more knowledge.

\section{REFERENCES}

Brown, James Dean. (1995). The Element of Languagr Curriculum: A Systematic Approach to Program Development. Boston, Massachusets: Heinle \& Heinle Publish.

Brown, James Dean. (1995). The Elements of Language Curriculum. Boston USA: An International Thomson Publishing Company.

De Zarobe, Yolanda Ruiz. Roaria Jimenez Catalan (Ed.) (2009). Content and Language Integrated Learning: Evidence from Research in Europe. Bristol, UK: Multilingual Matters.

Gall, Meredith D., Joyce P. Gall, \& Waiter R. Borg. (2003). Educational Research: An Introduction. Boston: Pearson Educations, Inc. 
Harmer, Jeremy. (2001). The Practice of English Language Teaching. Harlow Essex: Longman.

Kernan, James Mc. (2008). Curriculum and Imagination: Process Theory, Pedagogy and Action Research. New York: Routledge.

Nobert M. See \& Sanne Dijkstra. (2008). Curriculum, Plans, and Processes in Instructional Design. London: Lawrence Erlbaum Associates, Publishers.

Nunan, David. (1997). Syllabus Design. Oxford: Oxford University Press.

Richards, Jack C. (2005). Curriculum Develelopment in Language Teaching. New York: Cambridge University Press.

Sugiyono. (2013). Metode Penelitian Kuantitatif, Kualitatif, dan R \& D. Bandung: Penerbit Alfabeta. 